\title{
Creative Transformation: The Work of Conversion
}

AMERICAN PRAGMATISM represents a rich collection of arguments and issues that circulate around the transformation of life. This interest in transformation can make pragmatism appear less rigorous or less analytically powerful than competing philosophical models. My suggestion in this book, however, is that pragmatism aims to dwell within the power of philosophy that focuses on the systemic alteration of practice and the discovery of philosophical character. The rigor and analytic power the Americans seek can be measured only in the creative transformation of life, and developing the philosophical tools needed for this transformation is their primary concern.

In previous chapters I have dealt with the structures of transformation of which these philosophers are most aware. Peirce is most aware of the continuity of inquiry and practice and the realization of character within this continuum. Dewey is most aware of the emergent authority that makes criticism of practice both possible and productive in terms of growth. James is most aware of the psychological and personal dimensions of adjustment. Through these individual treatments, I have been trying to construct a broader argument that holds these philosophers together.

The cohesion of Peirce, James, and Dewey into a tradition depends on the strength of their philosophical approaches to incorporate conceptions of habit, inquiry, character, and authority around the pole of transformation. I do not think that these philosophers take it upon themselves to promote transformation in others or measure their success in this way. Rather, they perceive a transformation that is already present in their philosophical tradition and their culture. In this light, they devote their efforts to describing, illustrating, and expanding transformation in order to develop more access to its power and unveil its potential for being discovered through creative inquiry. The creative work of these pragmatists is bounded by transformation. This boundedness to the hope of a holistic transformation is the basis for their connection to Edwards 
that warrants my intuition that the problem of conversion is deeply embedded in the American philosophical enterprise.

In this chapter I want to extend the critique of transformation in American philosophy and begin to look at conversion thematically. Again, this is not an effort to incite transformation or conversion. Genuine transformation cannot be produced by argument but only by experience and discovery. While describing one's expectations may incline auditors toward the power of transformation, the pragmatists are confident that no person can manipulate this truth. Transformation is a reality that can be discovered with the help of another person or an intellectual guide, but unless transformation resists all efforts to become a function of utility or a domesticated form of thought it will only generate another semiotic iteration of ourselves. My claim is that the American philosophers are convinced that a genuine transformation of the form, content, and character of habits and inquiry is possible in experience. The origin of this transformation transcends experience and complete conscious control, but this transcendence can be discovered only by approaching the limit of self-consciously controlled change. The remainder of this chapter contains, first, some considerations concerning the shared methods of approach to transformation, especially in light of the religious character of this discussion in the pragmatists, and second, a thematic account of the transformation that becomes conversion.

\section{Historical AND THEOLOgICAL ARgUMENTS FOR TranSFORMATION}

Using transformation as an incorporative theme in the development in American thought, as I am doing here, has similarities to H. Richard Niebuhr's The Kingdom of God in America, in which Niebuhr argues that transformation is a fact of our culture through the presence of institutional Christianity. In some ways Niebuhr celebrates precisely what Dewey laments, the authoritative hold of Christianity on the expectations of common faith. Dewey could not displace this character, although he tried. But Niebuhr does not fear external critics such as Dewey as much as the internal loss of the church's identity and integrity. Niebuhr states, "I felt strongly that the times called for a rejection of 'Culture Protestantism' and for the return of the church to the confession of its own particular faith and ethos." The particular ethos Niebuhr is looking to is the sustained effort of the American church to transform 
itself and society under the power of the kingdom of God. The loss of this power in the church is evident in its inability to speak to the present conditions of social and religious life. In response to this loss, Niebuhr hopes to awaken this ethos by showing the development of constructive and formative resources of that faith. ${ }^{2}$ His method is most striking. Niebuhr simply describes the habit of historical American Christianity, doing "theology in the guise of history." He recalls the formative impulses in the figures central to American Christianity: "For the kingdom of God to which these men and the movements they initiated were loyal was not simply American culture or political and economic interest exalted and idealized; it was rather a kingdom which was prior to America and to which this nation, in its politics and economics, was required to conform." ${ }^{3}$ In this way, Niebuhr offers an understanding of American culture in relation to American Christianity by using this latter as the starting point. But Niebuhr also explores the transformation at the core of American Christianity as a historical resource for the present reconfiguring of the church and its faith. He has confidence that the pattern of transformation evident in the development of constructive Protestantism will provide the grounds for a recovery of this power. $\mathrm{He}$ struggles against the possibility that the content that inspired transformative work in our past will do so again. Transformation requires an ever new response, albeit a response that maintains the integrity of the community from which it extends.

Finding such an element of integrity and reformation is also evident in Ellen Charry's work on historical theology, By the Renewing of Your Minds. Like Niebuhr, Charry discovers a peculiar character within Christian doctrine. Although she sets out simply to read historical theology, Charry finds that a pattern emerges in those sources that connect them in a striking way. She says, "When Christian doctrines assert the truth about God, the world, and ourselves, it is a truth that seeks to influence us. As I worked through the texts, the divisions of the modern theological curriculum began making less and less sense to me. I realized I was uncovering a norm of theological integrity that had become unintelligible to the modern disciplines." 4 Charry identifies this norm as an aretological intention, that is, these texts aim to produce excellence in the readers. But accessing this theme means resisting the epistemological assertions of modern philosophy and their theological criticisms. "The modern understanding of reason, and truth constructed by Locke, 
Hume, and Kant is too narrow to be adequate for theological claims." 5 The theological claims she is principally interested in relate not to how one arrives at a better propositional basis for belief, but how one is to change, "to experience the nobility and truth of God whenever we use our minds rightly." She likens theological "knowledge" to the practice of medicine as a knowledge that also requires skilled judgment. "The proper practice of Christianity, like the proper practice of medicine, requires compassion and care and a watchful eye. In neither case can good treatment be limited to mechanical application of rules or practices." ${ }^{7}$ Recovering the category of skilled judgment enables Charry to reinvest biblical material with theological reflection. In relation to the Pauline school she writes, "Christian excellence is spiritual maturation effected by both a rehabilitation of mind and practiced behaviors that renew the self in the likeness of God (Eph. 4:17, 23-24). The imperatives of verses 17-24, urging readers not to return to the darkness of pagan futility, suggest that Christian behavior cannot be coerced. Although the author realizes the important role sociality and communal leadership play in Christian formation (4:11-13), the decision to luxuriate under the lordship of Christ and be guided by the Christian community, rather than wallow in impurity, must be undertaken intentionally. Humans are

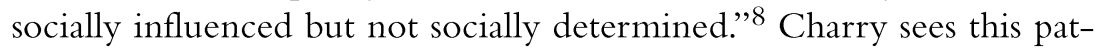
tern in theology that makes it a platform for discovering "fresh means of atonement," much as St. Paul suggests is the result of the response of the Gentiles to Christ in the letter to the Romans. The premise of theology is that this change offers new vantages for reading historical texts and making skilled judgments concerning immediate experience.

The consideration of whether transformation is a historical oddity or doctrinal characteristic peculiar to the Christian community finds its complement in the theology of David Ford. He appropriates transformation as a vehicle for expanding doctrinal questions into contemporary thought. Actually, Ford's question in Self and Salvation: Being Transformed is whether a theology of salvation can go to the heart of Christian identity. "How can an approach to salvation act as a focus for the gospel story in its biblical setting while also having universal implications?" 9 Instead of tracing out the historical power of conversion as Niebuhr does, or developing a synthetic theological vision as Charry does, Ford examines the transformation of salvation to see if it can collect the work of contemporary thinkers. He argues that it does, taking his lead also from Ephesians: 
"The message of salvation is that there is a new humanity which is already a reality in Christ and that even in relation to the deepest hostility (religious, racial, cultural, etc.) one starts from a situation in which the dividing wall has been removed, giving free access to God together." 10 $\mathrm{He}$ wends his way through the contemporary voices of Ricoeur, Levinas, and Jungel to display a language of transformation and conversion that is richly open to development.

Each of these three writers deserves an extended analysis. My point here, however, is to demonstrate three different directions from which the question of transformation can be fruitfully approached, and to suggest that each of these ways begins a kind of expansion that obliterates the charge of narrowness or cultic opacity often associated with conversion. My own direction into the question of conversion differs from these three. Rather than proposing that there is a truth that is accepted within culture but presently diminished in its power, or that the expectation of transformation has been present throughout the tradition and just needs a fresh unveiling, or that traditional sources of Christian transformation need additional power from an extension into contemporary voices, my argument is that the transformation of conversion emerges in the thought of the American philosophers when they try to do what philosophy does best, in critically evaluating the origin and prospects of thought and action. There is twofold character to this claim. First is discerning the limit of self-controlled transformation, and second, perceiving the reality of transformation that breaks beyond that power of self-control. Pragmatists move into this space, flowing back and forth between self-control and transcendent power. I cannot say that Christianity is or is not the most determining influence on the pragmatists' focus on transformation, but that neither strengthens nor diminishes this argument. The pragmatists' criticism of the demand for transformation clearly connects them with their religious culture, and it also becomes a platform for a creative transformation of philosophy. This is the element I find missing in the three theological models described earlier.

The power to mold a tradition on the basis of a critical advance sets the pragmatists apart. This is also what connects them to Edwards, whose tradition changing power is a result of his work on conversion. Edwards's clarification of conversion became the origin of a creative extension and transformation of American Christianity and culture that continues to influence us today. This extension stumbled intellectually under the 
leadership of his disciples in the New Divinity, but in many ways the pragmatists recovered this ground philosophically. This access from philosophy makes the transformation at the root of American intellectual and religious culture a different kind of discovery. It cannot be separated from the religious tradition; it is not a purely "natural" theology, but it is natural in the sense that any desire for transformation that emerges in experience is a sufficient ground for this philosophical inquiry.

\section{Themes OF THE CREATIVE TRANSFORMATION OF CONVERSION}

The purpose of this account of conversion is to make an advance on the self-critical awareness of the spirit of transformation that invests pragmatism. My goal is not to make something of the pragmatists that they are not. Rather, I am attempting to get a truer measure of the depth of their arguments for transformation by relating them to religious conversion and Jonathan Edwards. I believe that religious conversion is the proper framework within which a critical sense of the pragmatists' philosophical power may be brought to view and therefore also to a critical assessment. Just as Ellen Charry found an aretological impulse while reading historical theology, when I read Edwards, Peirce, Dewey, and James I find them leading to the question of ultimate transformation. In this section, I use a thematic description of conversion to follow these leadings. In the process I will try to demonstrate what keeps transformation present in their thought without it collapsing into a static theory or a dogmatic doctrine. This goes for Edwards as well, who finds flexibility in the meaning of conversion and expansiveness in the discovery of this life that opens into a continual process of creative transformation of the self and the community.

I have chosen to follow the four main themes I identified in Edwards's twelve signs of gracious affections for the structure of this general account of conversion. Using Edwards's themes as a guide makes it possible to integrate elements of transformation in the pragmatists with his expressly Christian fidelity, showing the resonance between Edwards and the pragmatists as well as their deepest points of conflict. Principal among these points of conflict is Edwards's Christological character of conversion that brings the evaluation of pragmatic transformation to a critical juncture. The four themes that bring us to this juncture are (1) aesthetic moral sense, (2) human understanding and the orientation of 
inquiry, (3) orienting content and the change of nature, and (4) the return to life conversion makes possible. This focus on the return to life as the telos of creative transformation is shared by Edwards and the pragmatists as the true good of revelation and reason.

\section{Aesthetic Moral Sense}

The first three signs of gracious affections cohere around a sense discovered in the affections that indicates an active and divine influence. Edwards begins his description of gracious affections by saying, "I. That they do arise from those influences and operations on the heart, which are spiritual, supernatural, and divine; II. The first objective ground of gracious affections, is the transcendentally excellent and amiable nature of divine things, as they are in themselves; and, III. Those affections that are truly holy, are primarily founded on the loveliness of the moral excellency of divine things" (RA 197, 240,253). The aesthetic sense of divine moral beauty is the unequivocal beginning of an inquiry into the ground necessary for transformation because it reveals the distinction between spiritual and natural excellence and the attraction that draws the heart from the natural to the spiritual.

One of the most difficult aspects of the Religious Affections and of any analysis of conversion is distinguishing between transformation as a completed act and transformation as a progressive discovery. Edwards seems to flip back and forth between these two, as is apparent in this first step of his argument. This ambiguity demonstrates that the transformation of conversion is a genuine moment of human and divine interaction, since otherwise conversion would be either only known as a preordained completion or only experienced as a temporal progression in our ideas. The preordained completed quality is evident in the attraction that would have no ground if not for the initiating influence of God, yet even this initial movement of the divine appears as a kind of invitation.

The divine initiative Edwards has in view is not general grace, but special grace that is saving if it is taken up as the initiation of an inquiry and opening up of the affections toward transformation. Thus, aesthetically motivated transformation can be followed into the realm of conversion. But the attraction to divine beauty is not a product of a temporal progression of ideas. While all beauty reveals a discovery of an 
order beyond the elements perceived, as the symmetry of a tune becomes apparent apart from the particular notes heard, the order of God's holiness is also perceived by a discovery of symmetry and harmony of acts that human thought can discover but not generate. And this realization of a spiritual discovery is, for Edwards, the opening or beginning of every experience of divine influence that begins an inquiry into transformation.

It is essential for Edwards that the discovery of transformation moves on attraction. Transformation is a response to gracious influence and love, because the method of revelation is continuous with the object revealed. The scripture speaks of the changed heart that loves God, and so this change must be brought about by love, not imposed against one's will or desire. Edwards does not claim that God is somehow ontologically prior within the understanding and then uncovered by some experience or rational principle. Revelation is part and parcel of the divine character of moral holiness, and the revelation of this character cannot be otherwise than an expression of this holiness. God's holy character is a human transforming holiness and so it can be known only in the reality of transformation. The creative transformation that Edwards discovers in himself is attended with the experience of his power to affect his own character through a response to an invitation to find something lovely. This love is not a mysterious element in transformation that eliminates or cancels human power of directed inquiry. The love of God's moral beauty provides a "first beginning and spring" of gracious affections for inquiring into the nature of aesthetic attraction that otherwise remains opaque in the affective lives of men and women.

The pragmatists reflect an aesthetic awareness of a moral quality that stands beyond them, although there is a reluctance to call it supernatural the way Edwards does. Dewey's sense of "what holds" him and his community in A Common Faith comes to mind as an example of this attraction that begins inquiry. In Dewey's thought, the sense of attraction to an order beyond the present order of practice comes in a powerful way, as does his trust that a "spiritual" order supervening on present practice is a great good and a satisfaction of human desire. James's sense of attraction to an ultimate moral claimant in "The Moral Philosopher and the Moral Life" also describes a kind of spiritual order that bears resemblance to God's holiness. In fact, James's identification with this moral sense of obligation and God's character is a pivotal moment in the development of his 
understanding of human will. James moves back and forth between the sense of attraction and obligation in connection to the divine, resolving finally on the side of attraction that must therefore dispel obligation. I think this original point of symmetry between obligation and attraction invests James's religious philosophy with a living tension.

Peirce is most clearly enrapt in the sense of aesthetic attraction to divine things when he speaks of "earnestly loving and adoring his strictly hypothetical God" (CP 6:467). God's moral beauty emerges in his account of the harmony within the universes of experience, a harmony that is not a static repetition of an ideal principle, but the discovery of an order that itself is growing and expanding in meaning. This living character of ideal is central to Peirce's notion of God, as he writes to William James in a letter of July 26, 1905 :

Forgive me for harping on the subject of theism, it is impossible for a person who puts metaphysical definitions aside to think that the object of one's love is not living. The idea is a vague one but it is only the more irresistible for that. . . . It is really impossible, except by sophisticating the plain truth, to think otherwise than that there is a living being. . . . So then what I mean by a living being is something approaching the nature of an ideal. I am far from ideal, it is true: but the shortcomings that make me so are out of harmony with something within me which would make me a thoroughly living being if it were not for those defects.

Peirce's awareness of the defects that prevent his being a "thoroughly living being" arise from the objective character of his love, but this love is also an opening for inquiry into the living character of an ideal of God. While Peirce does not associate this object of love with the holiness of God described in the scripture as directly as Edwards does, it is clear that the idea he is attracted to emerges with great consistency from his Christian religious experience. Just as James struggles to integrate obligation and attraction, Peirce struggles to integrate the universal attraction to God and his peculiar experience in the Christian tradition.

Where we may extend an analysis of Peirce, James, and Dewey via Edwards's spiritual sense is in relation to the claim that such an attraction constitutes a new principle of nature, and that this new nature and attraction are a kind of invitation to follow this inquiry into a fuller account of transformation. On one hand, the pragmatists work out of this confidence that a new kind of spirit is present in their thought and for people who desire this difference in reflective living. On the other 
hand, the pragmatists seem also to have this hope without ground. At this point Edwards draws confidence from his tradition: "The only certain foundation which any person has to believe that he is invited to partake of the blessings of the gospel, is that the Word of God declares that a person so qualified as he is, are invited, and God who declares it is true and cannot lie ... for the Scriptures are full of invitations to sinners, to the chief of sinners, to come and partake of the benefits of the gospel" (RA 223). If Edwards means anything in a global sense for American philosophy, it is confidence in the invitation to follow the attractive leading of mind and spirit into a progressive transformation that may yet become a conversion. Detracting from this desire to inquire into transformation or limiting the potential range or significance of transformation to me is an unpardonable philosophical sin.

Edwards's philosophical character is the best proof of the creative result of following this invitation to follow the aesthetic moral sense with productive inquiry. The challenge Edwards represents for the pragmatists is not to bend the knee to his tradition, but to match his inquiry into the springs of human thought and action. Edwards follows this aesthetic invitation with the articulation of the distinction between spiritual versus natural excellence, and in many ways this becomes the central issue of human transformation. Contrary to Dewey's assertion that classical philosophical and theological models privilege security and permanence of ideas, Edwards argues that the issue relating to the understanding is its transformation to a quality of character that is beyond what is presently available or even potentially available in action. Without a similar demand that our practice must exceed its own limits, the pragmatists have no ground for the reconstruction of habit they work for. Dewey's reconstructive urge turns precisely on the distinction between what has been the historical progress of reason and culture and what it should be in light of the fact that we have substituted the god of security and perfection for the God of democratic interactionism. This fructified interactionism is a kind of divine beauty for Dewey.

William James, as much as I think he substitutes himself for God, follows the attraction to the "more" in experience with powerful philosophical analysis. This analysis generates a unique vision of religious experience, in which transformation is a key component. I will not rehearse previous arguments about his views on conversion, except to make the point that Edwards and the pragmatists are very close in the 
ways they handle this attraction through cultivating and discerning the power of human understanding. But it is the differences here that show the richness and conflicts within the American reflective tradition.

\section{UNDERSTANDING AND THE ORIENTATION OF INQUIRY}

The distinction between the natural and spiritual senses of excellence leads to the second theme of transformation. Apart from this distinction, Edwards claims, there is no possibility of difference in human understanding that would amount to a real difference. The spiritual order in the understanding that incorporates the whole self becomes apparent only in relation to a divine ordering that is open for understanding through the truth discerned in the scripture. Also, like the initiating spiritual sense above, this order must be discoverable in experience and provide a platform for intentional direction and willed change. The signs that collect this theme of the effect on the understanding are "IV. Gracious affections do arise from the mind's being enlightened, rightly and spiritually to understand or apprehend divine things; V. Truly gracious affections are attended with a reasonable and spiritual conviction of the judgment, of the reality and certainty of divine things; and VI. with evangelical humiliation. Evangelical humiliation is a sense that a Christian has of his own utter insufficiency, despicableness, and odiousness, with an answerable frame of heart" (RA 266, 291, 311).

The internal dialectic central to Edwards's account of transformation appears very clearly in this section of the Religious Affections. From his philosophical reading Edwards knows the power the mind has to understand its own order. But this power can take possession and overrun the understanding that is of divine origin. Indeed, the mind begins with the discovery if its natural order and ordering power before it finds the spiritual order it was meant to exhibit. How this ordering potential of the mind follows out the discovery of the supernatural principle and discerns the disjunction between spiritual and natural excellence is the intimate version of the larger story of God's redeeming work in human history.

Edwards connects the potential ordering of the mind to the apprehension of an order within the habits that comprise one's character. Sang Lee juxtaposes Edwards's understanding of habits as constituting character to the Scholastic understanding of essential nature. The relation 
between actions and the relation of different relations emerge into a "dispositional ontology." Lee says, "To say that the abiding nature of entities consists in habits and laws is to maintain that entities are abidingly active tendencies. Things are essentially dispositional and thus inherently and unceasingly tending to actual existences through the exercise of habits and laws and through the immediate exercise of God's own power." ${ }^{11}$ The advance in human understanding that is possible only through divine transformation has to do with habits of understanding that reflect an emerging influence of divine power by becoming reordered in likeness to divine habits. Reordering habits by a spiritual influence requires that the natural understanding of habit is an analogical other to the divine, where the divine habit is distinguished as resolving to a single principle within the understanding and the will, eliminating any discontinuity internal to the habits of practice. The person becomes an instance of discovering the dispositional character of the divine character emerging in his or her own understanding. Indeed, persons cannot fully understand the sense of their heart without holding together their will and understanding as the source of habit formation emerging from their prior self-understanding. Transformation of the order of the understanding is central to Edwards's approach to conversion. He declares that such a discovery is the content basis of our ability to know our own transformation. The mind, Edwards says, is the proper seat of the affections.

Given the emphasis on changed habits of understanding, the conviction of the truth of the gospel concerning Jesus in sign $\mathrm{V}$ is less a matter of producing correct propositional truths than it is a feature of recognizing that the habit and tendency in recorded revelation is the same principle of order that discriminates the natural faculty of understanding from the spiritual. At this point in the Affections the conviction of the truth about Jesus is the sign of the discovery of the sense of the heartthis sense of the heart must have the divine order within scripture as its object in order to be awakened. Illumination can come no other way than by perceiving the order of divine habits in the narrative revelation of Jesus in the scripture taken as a whole. But the space of divine revelation is not limited by the particularity of the finite Christian tradition. Revelation is limited only by the human discovery that follows the opening that appears in the reflective understanding aware of its need for a sense of the heart. Edwards is sensitive to the deist charge that a peculiar 
divine revelation that is compatible with human understanding is challenged by the presence of non-Christian religions. Edwards responds to this charge by affirming a version of Origen's prisca theologia. This ancient doctrine holds that a divine and saving revelation stands at the root of all religions, not as a perfect original that degenerates in specificity or truth, but a permanent if obscured impulse toward reflecting the habit of divine tendency universally distributed in the power of human habit seeking order. ${ }^{12}$ There is light to follow in all traditions through which all people may discover the demand for a sense of the heart.

The pragmatic focus on the ultimate character of a transformation of the understanding follows the conviction that the mind is the seat of the affections. Pragmatic inquiry begins by challenging the bifurcation of willing and knowing in modern philosophy. Peirce's most common phrase defining his pragmatism is "you shall know them by their fruits." Further, the pragmatic argument that the division between thought and act is false couples with the drive toward discovering an order in thought and practice as the only method of productive inquiry into truth. The pragmatists clearly reflect Edwards's principle that the reflective life is not determined by the need for satisfactory responses to problems of reason but by the desire to develop a holistic response of the understanding and will to what is real. For this reason there are analogues to Edwards's sense of the heart in the pragmatists, principally apparent in the rejection of the modern philosophical platform of inquiry. The pragmatists demand a different heart of philosophical inquiry.

The analogue of the sense of the heart in Dewey is his projection of progressive intelligence developing new meaning in experience. Such progression implicates both the community and individuals in the same project, collecting the understanding of the communally driven impulse toward growth with the individual will to break beyond confining habits. Dewey recurs to the devotion of men and women for whom natural piety is the order of their action in discovering the task of democracy. The ultimate character of this coordination of understanding and will in a spirit of devotion appears in Dewey's pedagogic creed:

I believe that every teacher should realize the dignity of his calling; that he is a social servant set apart for the maintenance of proper social order and the securing of the right social growth. I believe that in this way the teacher always is the prophet of the true God and the usherer in of the true kingdom of God. (EW 5:595) 
The relation of this prophetic individual to the growth of the community is also apparent in Dewey's emphasis on the individual's settled act of will in A Common Faith. But beyond these platitudinous references, Dewey's appreciation of the discriminating force of this "sense of heart" comes out most apparently in his frequent rejection of the "supernatural" order of understanding. For Dewey there is no possible discovery of a coordinating sense between the community and the individual in relation to the traditional character of supernaturalism. ${ }^{13}$ Although I disagree with this analysis and have shown Edwards's rich sense of discovery in relation to the supernatural, I think Dewey is exactly right about forms of knowing that occur without due consideration of the relation of the heart and devotion. Where I think Dewey errs is his assumption that the supernatural always turns into a selfish desire for a private salvation. If Dewey had kept his focus on the inability to construct an order of the understanding simply by reference to private ends, and had avoided taking the "supernatural" as the generic failure of that attitude, I think his story of philosophical reconstruction would be much richer.

James reflects on the desire for a sense of the heart as a psychological function of the structure of religion. His suggestion that religious experience coincides with the development of the widest possible self reflects the same expectation that the understanding and will resolve into a single principle. The sense of the heart is not so much an individual achievement for James as it is a possibility determined by the framework within which religion and reflection are combined. In Varieties of Religious Experience he aims to alter the conceptual framework of religion in order to secure the ground for an accurate estimation of the prospects available for individuals. James does not worry about encouraging people to faith or witnessing to the power of the content he discovers, but he does intend to say where such content may or may not properly arise and what the effects of such content may or may not be within a properly refined understanding of both psychology and religion. James relies on the expression of the self in its deepest and most profoundly affective dimensions as the linchpin between the creation and the discovery of order in the reflective life. His preference for mysticism in the Varieties raises the content of the self to a religiously powerful discovery, primarily because of the limited criticism that can be brought to bear on it. This dependence on mysticism makes James's antithesis to Edwards's position clear, since for Edwards there is no 
motivating principle that can be cordoned off from critical evaluation. Even though James's focus on the personal dimension of religious experience is often associated with Edwards, their arguments about the difference in the capacity of human understanding in light of religious experience deeply conflict. James claims that one is justified in believing what one hopes to be true, or in our terms here, the sense of the heart is a product of intense appreciation of the content of one's anticipation of a more expansive personality. Edwards, as we have seen, resists any content as the order of the sense of the heart that would have to translate the Christ event into a private accommodation of one's prospective personality.

This conflict between James and Edwards over the order of understanding discovered in conversion brings to light a vitally important criticism of pragmatism. Apart from this conflict, the full dimension of James's alteration of the expectation of human understanding cannot be fully accounted. James argues that the understanding can attain the same affective order in terms of its effects as Edwards claims can occur only in light of the sense of the heart revealed in relation to Jesus. James's resistance to Edwards is the only way into this particular ground of criticism of the ordering of the understanding. The opposition centers on whether the order of the understanding is a personal creation, as in James, or that which is the result of a discovery in relation to a tradition, as in Edwards. American philosophy has pretty thoroughly handed over its religious concern to the spiritualism of human self that informs James's philosophy. This explains some of the tension that has developed between pragmatism and religion despite the clear religious characters of these three classical pragmatists, and despite William James's effort to isolate the peculiar good of religion. Pragmatists have repeated his criticisms while rejecting most of his positive attitudes toward religious activity, a response that has done more to isolate pragmatism from its full potential to reform American practice than any other philosophical habit.

Peirce, in nearly diametrical opposition to James, develops an account of understanding that depends on overcoming the "vagaries" of the self in order to approach real character. Peirce's emphasis on the Law of Mind discovered through the logical analysis of the continuity of thought, corresponds to Edwards's claim that human understanding seeks a completion of an ordering principle it cannot provide on its own. Peirce's notion of a developing character in human inquiry and Edwards's notion of conversion as a complete reordering of the understanding both avoid the 
problem of an ontological priority of a divine essence, at least in the phenomenological sense with which these claims become available and effective for ordering practice. Edwards and Peirce agree that claims, even ultimate ones like the final character of the individual and the universe, must be testable in practice. While Edwards does not propose a logical test of the "sense of the heart," I think a Peircean analysis of this aspect of transformation is appropriate. For if the sense of the heart cannot be described in relation to practice and doubt, I would agree with Peirce that it has no meaning.

The sense of the heart proposed by Edwards could be tested only by comparing it to an alternate ordering of the understanding that is shown to fail in comprehensiveness of self-understanding or self-control. This pragmatic evaluation would amount to showing what the "sense of the heart" makes possible in practice that another principle of understanding could not. The test for comprehensiveness requires an act that completely changes the order of understanding by virtue of a self-critically willed appropriation. I think this ground of a complete change in the structure of habit and habit formation appears in Peirce's "Neglected Argument for the Reality of God," although I think his effort comes up short in the end. Peirce realizes that the limitation of his synechism is that it cannot contain a terminus in action but only the infinitely distant telos of a continuous series. Conversion challenges Peirce's logic, and in fact, challenges it on its own terms in a way unavailable from any other position. Only the expectation of a complete change of the order of the understanding by virtue of an ideal that completely orients the will can bring Peirce's semiotic theory to its ultimate test.

Peirce more clearly diverges from Edwards over the principle of evangelical humiliation. The character of Peirce's agapism is really beyond the product of self-controlled inquiry, but when he comes at the issue from the side of logic, he claims that the character of agapism is immanent in the practice of pragmaticism. For if it is not a character that can be potentially realized it is a useless abstraction. If agapism means something we cannot perform, even in principle, even given the hypothetical distance of a temporal long run, then agapism is an idea that is discontinuous with our thought. We have reached the opacity of nominalism. Edwards might provide an interesting response to Peirce at this point concerning the negation that emerges in relation to the character aimed at in self-critical inquiry. Although there is no apparent limit to realizing 
such a character in practice, this completion cannot be attained in the same active production of the understanding that occurs in inquiry. Edwards's notion of evangelical humiliation might provide a further dimension of Peircean inquiry rather than a metaphysical meltdown. If pragmaticism would discover its own lapse by identifying the character it seeks to emulate, and, with this character, discover its inability to reproduce this in terms of a living content, then it would be closer to the truth concerning us. Even when we know the good, we do not do the good. Peirce does not have an appropriate category for the rejection he perceives at the end of his essay "The Law of Mind."

A difficulty which confronts the synechistic philosophy is this. In considering personality, that philosophy is forced to accept the doctrine of a personal God; but in considering communication, it cannot but admit that if there is a personal God, we must have a direct perception of that person and indeed be in personal communication with him. Now, if that be the case, the question arises how it is possible that the existence of this being should ever have been doubted by anybody. The only answer that I can at present make is that facts that stand before our face and eyes and stare us in the face are far from being, in all cases, the ones most easily discerned. That has been remarked from time immemorial. (CP 6:162)

Peirce's admission of puzzlement here pushes this analysis of the orientation of the understanding to another level. It is one thing to realize that the order the understanding gives itself is insufficient, as Peirce does. It is another thing to claim that the order that appears sufficient is still a deeper remove into absence. The question is how this principle of absence becomes the "foundational" term of the person, guiding the inquiry and habit development that generates truly self-critical expansion of the soul. In his description of evangelical humiliation in the Affections Edwards holds out a prospect of personal freedom that is different from Locke's notion that freedom is the ability to resist the last determination of the understanding. Locke's negative account of freedom builds from the notion that only an appearing good can become the focus of the will, although his account just pushes the question back one step. What does the will focus on if not the good appearing to the understanding? Without some space between the choice of the will and that appearing good, there is no ground for human freedom. Here the role of Edwards's sense of the heart is most clear. The sense of the heart follows from an evaluation of the great good of the affections, and yet it is not 
the same thing as cleaving to a principle that corresponds to that sense of the heart. The great good desired by the soul is not a disguised love of self but the genuine reflection of the desire for God's holiness as the order in the understanding, recognized as an order beyond the creative power of the will. The distinction between the transformation of understanding and conversion proper is the difference between desiring an order for the understanding and desiring the content that makes such an order possible. It is the love of the object that makes the will susceptible to the change of character that becomes a complete change of character. The choice for the object itself, not for the "object that orders the sense of the heart," is the basis of Edwards's argument in the Freedom of the Will. Free choice of the will cannot be seen in any particular choice, not even the choice of a holy order of the understanding, but only a choice to will as God wills for the soul, that is, that the soul has the will of Christ. Only in this way does the soul reflect the holiness of God in the true human freedom that "comprehends all the true moral excellency of intelligent beings: there is no other true virtue, but real holiness" (RA 255). The excellence that is truly the excellence of the human capacity for transformation is realized only in this complete alteration of the foundation of the person in willing to be as God wills.

\section{Orienting Content AND the Change of NATURe}

The most explicitly Christological aspect of the Religious Affections begins in this third theme of transformation that introduces the "complete change of character" that is Edwards's language for conversion. Edwards presents Christ as the central content of God's transforming work with humanity. This theme brings pragmatic conversion to a critical test. The signs comprising this theme are "VII. Gracious affections are attended with a change of nature;VIII. Gracious affections differ from those affections that are false and delusive, in that they tend to, and are attended with the lamblike, dovelike spirit and temper of Jesus Christ, or in other words, they naturally beget and promote such a spirit of love, meekness, forgiveness, and mercy, as appeared in Christ; and, IX. Gracious affections soften the heart and are attended and followed with a Christian tenderness of spirit" (RA 340, 345, 357).

For Edwards, the mystery of transformation appears most clearly in the discovery of content that changes the nature of the person. The 
interaction with the content of Christ becomes the orienting fact of the affections, not by dint of power, as in a compulsion of truth that cannot be denied, but by changing the desire of the soul to exercise its excellence. The mystery further appears in the manner that the soul knows this orientation because it has been changed. Otherwise the orientation of the affections remains opaque.

But why is Christ the content for such a change? We have seen that for Edwards the revelation of Christ is a principle that inhabits all scripture. But Christ also manifests a spirit of perfect submission to God's will for an order beyond himself. The self-effacing life of Christ, laying aside the power of a deity to become incarnate in order to redeem human life, is also the character every human can appropriate in discovering an order to the affections. God trusts Christ's sufficiency as the content by which all people may discover this orienting change. In pragmatic terms, the test of Christ's sufficiency is only the continuing and complete transformation of human life writ large.

This is firm ground for the pragmatists. The content they seek is that which will transform and change the nature of themselves and their community. James seeks the orientation to the self that reorients all activities toward this expansion. Such a change requires him, in a negative way, to set aside the orientation and change of Christian conversion. His opposition shows that his transformation is in the same neighborhood as Edwards, but they trust a different content.

For Dewey the change of character results from content developed exclusively in experience. Thick experience becomes the orienting ground of Dewey's transformation, and individual or communal change is oriented by an emergent or growing content of experience. This focus on the content of experience approaches Edwards's Christological ground in the sense that conversion must have individual and communal dimensions. The content of experience must provide orientation for both. Dewey is aware of the power of Christian conversion in terms of producing a different kind of life that manifests openness to change and a lamblike spirit of service to the community. Dewey's vision of the democratic community is a naturalized replacement for the content of Christ that serves as both the content needed for a change of personal character and as the ideal all people seek. Although Dewey claims that his democratic vision is a broadly held ideal, this claim goes begging in terms of its effectiveness to produce a change in human character. There 
is no tradition of personal transformation built around the realization of the democratic community like there is concerning Christ. Democracy is a powerful idea that orients practice toward more fruitful and humane ways of interacting, but proposing that democracy is the content of orientation for all human transformation exceeds propriety. Still, Dewey seems faithful to the mystery of an orienting content that produces human change to the bottom of the heart. I think that Dewey's democratic faith is a kind of orchidism of the universal aspect of Christological content; it is the flower without roots or stalk. Dewey carefully tends the attraction of the democratic ideal in the hope that its universal appeal will determine the character of transforming content.

Peirce models the continuing inquiry that an orienting object such as Christ sustains. The complexity of the self, locked in the semiotic folds and expansion of meaning, matches the complexity of the continually receding object of inquiry. This content keeps slipping away from Peirce, both in terms of a change in himself and in terms of the content his inquiry seeks. Pragmaticism is an orientation in inquiry toward that which always draws it forward. This drawing forward implicates the normative progression of the control of behavior with the normative progression of conclusions of inquiry. The mystery of Christ for Peirce, if I may use such an allusion here, is the harmonization of human thought and action by one content-although that content always remains beyond cognitive realization. This model of transformation coincides with Edwards's suggestion that conversion is a continuous project, and that gracious affections reflect a tenderness of spirit that increasingly takes on the character of Jesus. Peirce interprets this as the fundamental urge toward the gospel of Christ where every man casts in his lot with his neighbor. But Peirce cannot formulate the realization of this character in a way that would not end inquiry. Continuous inquiry becomes not only the means but also the object for Peirce. Even though Christ for Peirce is the continuum of action and thought, and not a "miracle monger," he still hears the call of the savior and is granted permission by the Master to take communion. The focus on content that I am raising here challenges Peirce's inquiry to find an object that is consistent with his notion of continuity and yet provides a platform for practical or moral orientation. A practical conversion like this would strengthen Peirce's concept of the self as both oriented inquiry and distinct expression of normative realization. To repeat my point in the last section in a 
slightly different way, this addition of conversion requires Peircean thought to account for a different aspect of negation as a holistic error of orientation. Again, it is possible to discover this error only in light of a positive orientation that becomes the root of comprehensive change in a person. Such a change of character eluded Peirce in his lifetime, as Joseph Brent documents. His dissatisfaction with his own character and his feeling that he had squandered his gifts is a sad ending to a life of service to inquiry and philosophy. We may try to redeem Peirce by our appreciation, but our redemption has its limits. Real redemption follows only if Peirce's example enables us to seek, as he did, and to find, as he did not, a truly redeeming content.

\section{ChristologicAl GROUND IN CONVERSION}

In this portrayal of the intersection of pragmatic transformation and Edwards's conversion, I have indicated at several places how Christ emerges as a point of conflict or challenge to philosophy. I have done so at the risk of producing an abrupt disjunction between transformation and conversion, so I think it is appropriate to pause in this account of transformation to dwell on this issue of Christ. The first point to make, however, is that Edwards, as a sign of fidelity to his tradition, adjusts the meaning of Christ in relation to the transformation of human life. The test of creative transformation for Edwards is the manner in which his theological tradition reflects openness to appropriate modification. In this sense, conversion is continuous with philosophical transformation. Both aim to appropriate the content necessary for full human life. The pragmatists resist the claim that Christ is the limit of creative transformation. This raises the bar on Edwards, so to speak, to find in Christ the ground for a creative transformation of his tradition that corresponds to the American philosophical desire for a transformed tradition. If no aspect of creative transformation emerges from a positive relation to Christ, then this study comes to a quick conclusion. In this case, conversion in American philosophy is not possible.

One way that Edwards negotiates the issue of Christ in his tradition is by pointing out what appears to ground a theology of conversion, that is, that such a transformation must coincide with a natural human quality. Only if Christ is the expression of a natural power of human character can there be continuity between conversion and human action. Conrad 
Cherry locates this impulse in Edwards's proposal of Christology that mediates between the Calvinist conviction that man has no power to achieve salvation, and the Arminian claim that salvation depends on a human act of faith. He summarizes the point in this passage:

The crux of this proposal is Edwards's distinction between "natural" and "moral" fitness. Faith is a "naturally" fit, not a "morally" fit relation. A person is morally fit or suitable for something when his own moral goodness, holiness, or excellence commends him to it. So, if one were morally fit for salvation or justification, the holiness or excellence of his act of faith would commend him to salvation. Then God would reward man with salvation because God respected the "moral excellency, or value or amiableness of any of his qualifications or acts." On the other hand, one is naturally fit for something by virtue of the "natural concord or agreeableness" that exists between the human qualification or act and the reality that is attached to that act. Here man is naturally fit for salvation by faith because the two things belong together. God does not reward man with salvation because of the holiness of man's own act; rather, He looks on it as fitting that two things that belong inseparably together, are together; and out of His love for order He sees to it that Christ's righteousness flows to man through the union that man has with Christ through faith. ${ }^{14}$

On one hand, the proposal that faith in Christ is a natural fit or order of human consciousness seems to beg the question. But in light of his tradition and experience Edwards discovers a need to inquire further into the tradition of conversion without dismantling it. The fitness of human nature for Christological transformation restores a sense of humanity to his tradition that is sometimes absent in Calvinism. The transformation Edwards describes extends beyond the limits of Reformed theology and into the nature of man and the products of reason. It also extends beyond the Arminian demand that persons choose their own value apart from any prior ground of grace. Edwards's argument for "natural fitness" confirms the character of human inquiry as an adequate approach to the original nature. Within this approach the revelation of Christ is fully manifested, and thus Edwards alters his tradition on the ground of securing the possibility of creative transformation.

Transformation, however consistent with our nature, still rests on the fact that Christ is the principle of revelation. Gerald McDermott notes Kinmach's summary that "Edwards came to the conclusion that while fallen reason can prove religious propositions to be true, it cannot make them seem real." McDermott then quotes from Edwards miscellanies to 
support the point that the reality of divinity depends on revelation. Natural truths, Edwards says, are not taught

in that manner in which it is necessary for us to know it, for the knowledge of no truth of divinity is of any significance to us any otherwise than it some way or another belongs to the gospel scheme, or has relevance to Christ the Mediator. It signifies nothing for us to know anything of any one of God's perfections unless we know them as manifested in Christ, and so it signifies nothing to us to know any part of our duty unless it will [bear] some relation to Christ. It profits us not to have any knowledge of the law of God, unless it be either to fit us for the glad tidings of the gospel or to be a means of our sanctification in Christ Jesus and to influence us to serve God through Christ by an evangelical obedience and therefore we stand in the greatest necessity of a divine revelation. ${ }^{15}$

In these lines we see that Edwards identifies Christ as the principle that makes intellectual discovery real in terms of its having a role in God's large scheme of revelation. Christ is the criterion of understanding that supports the realization of God's intention to transform humanity through an ultimate realization of fitness. Our great need for revelation is shown by the reality of Christ in our discoveries that become part and parcel of our realization of divine transformation. Without such a mediating content, our efforts to discover transforming truths would fail.

For Edwards, Christ is above all else the assurance that our desire for transformation is not in vain. H. R. Niebuhr says, "Yet faith is not simply loyalty; it is assurance, too. It is confidence in the object toward which the inner passion is directed. It is the trust that the cause will not fail us, will not let us down. Such trust, to be sure is mated with a kind of objective uncertainty; but it is not the uncertainty that makes it faith."16 Christ is the object that, for Edwards, assures human passion and trust in the possibility of transformation is not an empty hope.

Edwards finds room in the meaning of Christ to transform his understanding of the cosmological force of inquiry and practice toward a prospective integration. Through this integration it is possible to anticipate practice that perfectly reflects the best order of the mind. Christ is the ground of this complete reorientation of practice that reveals a fundamental change in character. This expands the meaning of Edwards's traditional view of Christ as the image of both perfect moral practice and complete self-understanding through the will of God. But Edwards's vision of Christ alters his tradition, and it is this power of tradition altering 
inquiry that forms the ground of the pragmatic philosophical tradition. Edwards's fidelity to Christ makes it possible to transform his tradition creatively. Through his encounter with Christ, Edwards finds that his tradition becomes a way of discovering not only the ultimate character of divine reality but also the reality of our own practice seen through the lens of its possible transformation. Edwards's transformation of the tradition focuses on confronting the person with the questions "Is Christ good. Is Christ of God?" Edwards has confidence that raising this question with all possible power is the true measure of his subordination of his efforts to the will of God. This confidence appears in his philosophical project that arrives at the same question; "How does Christ become implicated in the reflective transformation of life?"

The question of conversion for the pragmatists is what to do with Christ. In their critical assessment of transformation, pragmatists must offer a rebuttal showing how Edwards's Christological conversion fails in terms of providing an order of the understanding or as the ground for transforming tradition. Pragmatists must respond to Edwards's account of a holistic change in the person that affects a reorientation of the understanding and the tradition, in such a way that apart from this holistic change nothing is good that may appear good. But this challenge also moves from the pragmatists toward Edwards. The Christological dimensions in the pragmatists raise new questions about the sufficiency of a model of conversion, like Edwards's, to interact positively with the philosophical tradition. Pragmatism pushes conversion continually in the direction of creative transformation.

\section{RETURNING TO LIFE THROUGH CONVERSION}

There are two purposes behind Edwards's Religious Affections. One purpose is to justify the occurrence of the revival and to provide a warrant for that revival as a genuine work of God. The second purpose is more creative, in the sense that Edwards trusts that his examination of conversion will support and extend the lives of the saints through an active inquiry into their transformation. I think that these two purposes fall together for Edwards. The genuine work of God generates the life of the saints, at least that which makes them peculiar and separate from a "natural" human life. The principle of Christ distinguishes the transformation of conversion from natural transformation. Edwards focuses on the 
product of living in this distinctive way in the last three signs: " $\mathrm{X}$. Another thing wherein those affections that are truly gracious and holy, differ from those that are false, is beautiful symmetry and proportion; XI. Another great and distinguishing feature of gracious affections is that the higher they are raised, the more is a spiritual appetite and longing of soul after spiritual attainments increased. On the contrary, false affections rest satisfied in themselves; and, XII. Gracious and holy affections have their exercise and fruit in Christian practice. I mean, they have that influence and power upon him, who is the subject of 'em, that they cause that a practice, which is universally conformed to, and directed by Christian rules, should be the practice and business of his life" (RA 365, 376, 383).

The goal in these last signs is to describe a form of living that increases the harmony within the active and reflective life of the person. The demonstrable effect of this changed life is a recognized obedience to "Christian rules," according to Edwards. Proof of an altered inclination can have no other "logical interpretant" to use Peirce's language, than a life. This demand for proof of the change wrought in transformation by examination of one's living is in continuity with the pragmatic tradition. Edwards and the pragmatists hold up this ability to return to life as the final criterion by which any transformation, divine or natural, can be judged. Discovered truths are known fully only if they are implicated in the practical stuff of life. This may be reversed to say that only within the practical stuff of life is the platform for discovering the ultimate aspects of transformation and conversion truly possible.

\section{The Woman AT THE WeLL}

Instead of describing the force of this last aspect of transformation in terms of Edwards and the pragmatists, I am going to reflect on a story that all these thinkers would agree demonstrates an experience of transformation and conversion. I have chosen this story for two reasons. First, I think it provides a fitting conclusion to this positive statement of creative transformation-although there are disagreements in part, I believe that Edwards's notion of conversion and the pragmatists' view of transformation reconnect in a powerful way in terms of a story about returning to life. Second, the account of this woman's interaction with Jesus that occasions a return to her community illuminates the interplay between reflective transformation and conversion within a dialogue based on religious 
tradition and reflective access to that tradition. This story is not only a fitting image of conversion; it is also a sign of the human desire for such occasions and the discoveries that form the continuity within human life from which transformation grows as a demand and as a hope.

The account of the woman of Sychar and Jesus (John 4:1-43) reads this way in the Revised Standard Version:

Now when the Lord knew that the Pharisees had heard that Jesus was making and baptizing more disciples than John (although Jesus himself did not baptize, but only his disciples), he left Judea and departed again to Galilee. He had to pass through Samaria.

So he came to a city of Samaria, called Sychar, near the field that Jacob gave to his son Joseph. Jacob's well was there, and so Jesus, wearied as he was with his journey, sat down beside the well. It was about the sixth hour.

There came a woman of Samaria to draw water. Jesus said to her," Give me a drink." For his disciples had gone away into the city to buy food. The Samaritan woman said to him, "How is it that you, a Jew, ask a drink of me, a woman of Samar'ia?" For Jews have no dealings with Samaritans. Jesus answered her, "If you knew the gift of God, and who it is that is saying to you, 'Give me a drink,' you would have asked him, and he would have given you living water." The woman said to him, "Sir, you have nothing to draw with, and the well is deep; where do you get that living water? Are you greater than our father Jacob, who gave us the well, and drank from it himself, and his sons, and his cattle?" Jesus said to her, "Every one who drinks of this water will thirst again, but whoever drinks of the water that I shall give him will never thirst; the water that I shall give him will become in him a spring of water welling up to eternal life." The woman said to him, "Sir, give me this water, that I may not thirst, nor come here to draw." Jesus said to her, "Go, call your husband, and come here." The woman answered him, "I have no husband." Jesus said to her, "You are right in saying, 'I have no husband'; for you have had five husbands, and he whom you now have is not your husband; this you said truly." The woman said to him, "Sir, I perceive that you are a prophet. Our fathers worshiped on this mountain; and you say that in Jerusalem is the place where men ought to worship." Jesus said to her, "Woman, believe me, the hour is coming when neither on this mountain nor in Jerusalem will you worship the Father. You worship what you do not know; we worship what we know, for salvation is from the Jews. But the hour is coming, and now is, when the true worshipers will worship the Father in spirit and truth, for such the Father seeks to worship him. God is spirit, 
and those who worship him must worship in spirit and truth." The woman said to him, "I know that Messiah is coming (he who is called Christ); when he comes, he will show us all things." Jesus said to her, "I who speak to you am he."

Just then his disciples came. They marveled that he was talking with a woman, but none said, "What do you wish?" or, "Why are you talking with her?" So the woman left her water jar, and went away into the city, and said to the people, "Come, see a man who told me all that I ever did. Can this be the Christ?"They went out of the city and were coming to him.

Meanwhile the disciples besought him, saying, "Rabbi, eat." But he said to them, "I have food to eat of which you do not know." So the disciples said to one another, "Has any one brought him food?" Jesus said to them, "My food is to do the will of him who sent me, and to accomplish his work. Do you not say, 'There are yet four months, then comes the harvest'? I tell you, lift up your eyes, and see how the fields are already white for harvest. He who reaps receives wages, and gathers fruit for eternal life, so that sower and reaper may rejoice together. For here the saying holds true, 'One sows and another reaps.' I sent you to reap that for which you did not labor; others have labored, and you have entered into their labor."

Many Samaritans from that city believed in him because of the woman's testimony, "He told me all that I ever did." So when the Samaritans came to him, they asked him to stay with them; and he stayed there two days. And many more believed because of his word. They said to the woman, "It is no longer because of your words that we believe, for we have heard for ourselves, and we know that this is indeed the Savior of the world."

This setting is one of the most fleshed out vignettes in the gospel tradition, and the writer was assiduously aware of geography, local custom, and religious history of the Samaritans. But the setting makes sense only because of the dialogue between these two who met by chance at a well. In a sense, they were both hiding. Jesus was trying to move without raising the attention of the Pharisees, and the woman was hiding from interaction with other water gatherers who would choose either a closer water source or a cooler time of the day. She wanted to be alone, and the choice of Jacob's well was intentional. ${ }^{17}$

The dialogue that emerges between these unlikely partners flows between Jesus' breaking social barriers in initiating the conversation, and the woman's deflective and pithy rejoinders. She knows where she is and she knows what separates him from her. When he reveals her marital 
excesses, she points him to the Jewish excesses of claiming Jerusalem as God's chosen place of worship without any scriptural backing. ${ }^{18}$ In this repartee, Jesus finds the place to reveal himself. The Samaritans expected a prophet like Moses, a Taheb, a prophet who returns, who will sort out the problems of their racially mixed past and their conflict with the Jews. ${ }^{19}$ "I, the one speaking to you, I am the one," Jesus says.

Jesus' claim that he is the restorer she seeks is the last word recorded between them. The woman leaves when the disciples, oblivious of the interchange that has taken place, come back. Whatever meaning the words had that passed between them the result was that the woman returns to her village and proclaims, "Come see the man who told me everything I ever did. Could this be the messiah?" It is this return that makes the difference in the narrative. From her isolated venture to the well, the woman receives a word that bubbles out of her, and she shares the prospect of a spiritual return that the people of her village desire as well. There is no time to stop and discern the meaning of the tradition, there is only the word of confession that prompts the people to come and see for themselves the source of this restoration.

The creative transformation in this narrative in John's gospel is typical in many ways of the gospel tradition that inspires Edwards and the pragmatists. The word that strikes into their experience exceeds the form of its first apprehension, and explodes in significance for themselves and their communities. This creative word is often overlooked by the very groups who are identified with it, like the disciples in this story, so there is no sense in trusting an institution to bring about this discovery. The founding figures of American philosophy desire to return to their communities with a saving word, as this woman does. They long to construct an encounter with truth in the ordinary paths of life that would bring new meaning and a new orientation to the activity of life itself. This is the desired return that I find coursing through the tradition of American philosophy. The desire for the creative transformation of life is the goal that connects the philosophical work of the pragmatists and conversion.

\section{Notes}

1. James W. Fowler, To See the Kingdom: The Theological Vision of H. Richard Niebuhr (Abingdon, 1974), 98.

2. Ibid., 116. 
3. H. Richard Niebuhr, The Kingdom of God in America (Wesleyan University Press, 1988), 10.

4. Ellen Charry, By the Renewing of Your Minds (Oxford University Press, 1997), viii.

5. Ibid., 9 .

6. Ibid., 147.

7. Ibid., 15 .

8. Ibid., 53 .

9. David Ford, Self and Salvation: Being Transformed (Cambridge University Press, 1999), 2.

10. Ibid., 115.

11. Sang Hyun Lee, Philosophical Theology of Jonathan Edwards (Princeton University Press, 1988), 50.

12. McDermott, Jonathan Edwards Confronts the Gods (Oxford, 2000), 96.

13. Douglas R. Anderson, "Smith and Dewey on the Religious Dimension of Experience: Dealing with Dewey's Half-God," American Journal of Theology and Philosophy 14, no. 2 (May 1993): 167.

14. Cherry, The Theology of Jonathan Edwards (Indiana University Press, 1966), 97.

15. McDermott, Jonathan Edwards Confronts the Gods, 65-66.

16. H. Richard Niebuhr, Christ and Culture (Harper \& Row, 1951), 252.

17. F. F. Bruce, The Gospel of John (Eerdmans, 1983). Bruce points out (101ff.) that if the traditional place of Sychar is the modern Askar, the trip to Jacob's well would take her past another fountain and across a stream.

18. Ibid., 109.

19. Raymond Brown, The Gospel According to John I-XII (Doubleday, 1966), 172. 